e-ISSN: 2550-1313 | p-ISSN: 2087-9849

http://jurnal.fkip.unila.ac.id/index.php/jpp/

\title{
Vlog Project or Picture Series: Examining Effective Techniques in Teaching Speaking Skills
}

\author{
Nunik Herani Wulandari*, Ashadi \\ Department of English Education, Universitas Negeri Yogyakarta, Indonesia. \\ *Corresponding email: nunikhwulandari@gmail.com
}

Received: 24 July 2021

Accepted: 27 August 2021

Published: 27 August 2021

Abstract: Vlog Project or Picture Series: Examining Effective Techniques in Teaching Speaking Skills. Objectives: This study investigates whether there are significant differences between students who are taught using the vlog project and picture series techniques. Methods: Quasi-Experimental method was used to collect information through two groups as experimental, and one control group, the number of samples is 58 students. The data obtained were analyzed using ANOVA test and continued with the Scheffe test. Findings: The findings in this study reveal that the use of the vlog project technique is, to some extent, more effective than the use of picture series and conventional techniques. It is evidenced by the value of the mean difference in the Scheffe test, which is positive for the other two groups, namely 2.70760 and 5.46316. Conclusion: vlog project technique significantly affects the teaching-learning process of speaking in the eighth grade, especially for recount text.

Keywords: teaching techniques, speaking skills, vlog projects, picture series.

Abstrak: Vlog Project \& Picture Series: Menguji Teknik yang Efektif dalam Mengajar Keterampilan Berbicara. Tujuan: Penelitian ini menyelidiki apakah ada perbedaan yang signifikan antara siswa yang diajar menggunakan teknik vlog project dan picture series Metode: Metode Quasi-Experimental digunakan untuk mengumpulkan informasi dalam penelitian ini melalui dua kelompok sebagai eksperimen dan satu grup kontrol, total siswa sebagai sample adalah 58. Data yang diperoleh dianalisis menggunakan ANOVA test dan dilanjutkan dengan Scheffe test. Temuan: Penemuan dalam penelitian ini mengungkap bahwa penggunaan teknik vlog project, sampai padabatas tertentu, lebih efektif daripada penggunaan teknik picture series maupun teknik konvensional. Hal ini dibuktikan dengan nilai mean difference pada scheffe test bernilai positif terhadap kedua kelompok lainnya,yakni 2.70760 dan 5.46316. Kesimpulan: Teknik vlog project secara signifikan mempengaruhi proses belajar mengajar berbicara di kelas delapan, terutama untuk teks recount.

Kata kunci: teknik mengajar, keterampilan berbicara, vlog project, picture series.

\section{To cite this article:}

Wulandari, N, H., \& Ashadi. (2021). Vlog Project or Picture Series: Examining Effective Techniques in Teaching Speaking Skills. Jurnal Pendidikan Progresif, 11(2), 275-289. doi: 10.23960/ jpp.v11.i2.202111. 


\section{INTRODUCTION}

The skills to speak are the most skills learners want to learn, among other skills. That is because language learners want to be able to communicate verbally in mastery and fluent manner. It is in line with what was said by Richard and Renandya (2002), who identified that most English language learners have the goal of speaking. Richards (2008) added that students evaluate the level of English proficiency through how fluent they are in communicating orally. In other words, the prerequisite for achieving success in learning a language can communicate fluently verbally. Therefore, speaking skills are fundamental in successful language learning.

Speaking is an activity to express ideas to the listeners so that sometimes interactions occur. Speaking objectives vary widely depending on what the speaker wants to achieve (Thornbury, 2005; Spartt et al., 2005). Based on the explanation, they show that speaking is not limited to how to make listeners understand what the speaker is saying, but listeners also understand its intent and purpose. The statements also show that speaking is equally important and has the right to receive massive attention, similar to the other three skills in English since speaking is an activity that people do every time to communicate.

The 2013 curriculum has prescribed all language skills must be mastered, namely listening, reading, speaking, and writing. Based on the curriculum junior high school students must be able to compose concise and simple texts orally. Moreover, they must be able to arrange the text verbally by paying attention to the purpose of delivering the text. They have to tell the text in an applicable logical sequence, then use the correct tenses, sort and select the appropriate vocabularies, and express words according to the prevailing pattern are several provisions that must be followed because they are used as a benchmark for developing the speaking skills of the learners.
Many ways can be considered to build speaking skills. Choosing teaching and learning techniques that suit the needs of the learners so that the learning objectives can be achieved is one of them. Gerlach and Ely (1980) state that A technique is a path, tool, or medium used by the teacher to direct students' activities towards achieving goals. Thus, in the implementation of teaching and learning activities, to achieve learning objectives, away is used in the form of teaching techniques that can effectively help learners achieve their learning goals.

In the teaching-learning process of speaking skills, Brown (2000) suggests several principles that must be considered when designing learning techniques. These principles cover the needs of learners in learning speaking, provide learning that motivates and arouses learners' desire to achieve learning objectives, provide meaningful learning, provide feedback and correction, and convince students to be able to develop valuable strategies to help them achieve their goals of speaking skill learning objectives.

Although guiding principles are available, many teachers still believe in the conventional technique (Marmah, 2014; Li, 2016; Mokhtar, 2016). This technique is a learning process that places students as learning objects that passively receive learning information and the teacher becomes the center. Usually, the learning process uses lectures, questions and answers, and assignments as learning methods. In essence, in the learning process, learners only carry out two activities: listening and taking notes or one-way learning (Sanjaya 2006; Djafar 2001). The same thing is also explained by Nasution (1982), Ruseffendi (2005), and Djamarah \& Zain (2006), where the characteristics of conventional techniques are that the teaching-learning process is more concerned with memorization. It does not require a long time in learning because the activity is centered on an explanation of the material that manylearners can follow. In addition, 
the learning process is passive and dominated by teachers and does not provide much feedback given in learning. Instead, it is done through lectures and assignments. Therefore, the things that have been described do not meet the principle criteria that must be considered when designing teaching techniques.

After reviewing and considering teaching techniques based on the principles in designing teaching techniques, vlog projects and picture series seem to fit into the criteria described to be used in the teaching and learning process of speaking skills. This statement is supported by Anil (2016), who claims that the vlog project technique arouses the motivation and curiosity of the learners in the learning process. Moreover, vlogging increases the time for learners to talk. The longer students have to communicate verbally, the more students' mastery of vocabulary addition and grammar mastery will increase. Therefore, using the vlog project technique, students can set their own speaking practice time without thinking about the minimal learning time limit in class. In addition, if the students are not satisfied with the vlogs they have made, they still have the opportunity to repeat the vlogs while still working on the project. They can repeat it until they find it satisfactory (Watkins, 2012).

More specifically, the concept of vlog project learning is the project method. Stoller (2002) describes The project method as "a natural extension of what is already taking place in class." So it can be concluded that the project is conducted outside as the follow-up of classroom learning activity. Real-world subjects and topics of students' interest become the most important thing to the learners. In addition, the project work is student-centered. The teacher has only a small role as a supporter and giving guidance on the project completion process. It is in line with Krauss \& Boss (2013) and Kýzapan \& Bektap (2017), explaining that project-based learning is a student center. In this teaching technique, learners must solve the problems they face and seek information related to the projects they are working on to theorize, investigate, collect, analyze, create, and draw conclusions from the valuable information. In addition, the vlog project combines technology that is well known in the modern era with the learning process. The use of this technology can attract attention and raise the desire of learners to develop projects that the learners do as well as possible because their work will be disseminated online later (Patton, 2012).

While the picture series are several pictures arranged in sequence to tell an event, the pictures help give an outline of the storyline (Wright, 1989). Teachers can use picture series to stimulate learners to produce verbal expressions and help them overcome grammar and vocabulary problems (Wright 1989; Harmer, 1991; Harmer, 2004). Further to this, in teaching and learning activities of speaking skills, pictures motivate to speak. Using pictures, the teacher indirectly provides a material to be discussed following the theme or things that the students have to talk about in focus and depth (Bailey, 2005). In conclusion, the pictures guide students in terms of organization text, use the necessary vocabulary and use the sentence structure that should be used.

Many studies have provided evidence that vlog project and picture series can effectively help to achieve English mastery. These studies show the techniques effectively helps to improve writing skills (Andayani, 2016; Iman \& Anggraini, 2016; Pratiwi, 2016), speaking (Hung, 2011; Anil, 2016; Rakhmanina \& Kusumaningrum, 2017; Nasruloh, 2013; Iman \& Anggraini, 2016; Zainatuddar, 2015; Nugroho et. Al, 2015; Marzuki \& Nurpahmi, 2019; Ahsin, 2020), and reading (Amsiana et.al, 2014).

In more detail, in the vlog project, a study was conducted by Hung (2011). The results showed that the learning process with Vlog gave excellent outcomes. Students acknowledge that vlogging was a practical tool for learning speaking. 
showed that vlogs helped the students to learn independently. Based on this research, the vlog project could be considered as an interactive activity for students because, by it, they were able to assess their own performance, and were able to assess which parts of learning still need improvement; students had a longer time limit than doing assignments in class thus they were able to repeat project work if they were not at the satisfying stage yet; students could judge for themselves what level of progress their speaking skills were developing at; vlog project provided facilities for peer feedback on created vlogs; students' motivation increased because they felt challenged to make the best vlog by giving editing effects to the videos they produced until they felt satisfied.

Other research also identify that vlog projects can be considered for use in the teaching and learning process (Anil, 2016). This research indicates that Vlogs provide a significant change in students' speaking skills. Vlogging is a communicative activity that can be used as a way of practicing speaking skills. In addition, the teaching and learning process using the vlog project received a positive response from the learners. The students showed a high level of interest in the learning process. The students thought that Vlogs were a means to learn English joyfully. Then, the research conducted by Marzuki \&Nurpahmi (2019) also showed that vlogs could help learners to improve their speaking skills of the learners. That is evidenced by the average post-test score obtained, which is higher than the average pre-test score. Similarly, Ahsin (2020) explains that his research showed a significant difference between learners who were treated with the vlog project technique and not. The average value obtained is also higher than the control group. A study with similar results was also conducted by Rahmawati et al. (2018), which explains that the classroom conditions become more conducive and students actively participate and enjoy the teaching and learning process.

Similarly, research related to picture series was conducted by Purwatiningsih (2015). The results showed that the speaking ability of the learners increased, especially in the aspect of pronunciation. In addition, the students are very focused and show curiosity and interest during the teaching and learning process. Research with similar results was also shown by other researchers, where the results showed that by using picture series, students could build speaking skills in terms of fluency, content, pronunciation, and grammar. In addition, picture series can generate motivation, making learners more active, creative, independent, and confident in expressing the ideas that learners have (Karsono, 2014; Zainatuddar, 2015; Zulaikah, 2017).

Likewise, other research related to picture series was conducted by Purwatiningsih (2015). The results showed that the learner's speaking skills improved by using picture series, especially in pronunciation aspects. Besides that, students also actively participated in the teaching and learning process. The learners gave their full attention and focus on learning activities. Students showed interest and curiosity. It was evidenced by the active learners when they asked about the learning material.

Other studies showed similar results. By using picture series, students could develop speaking skills in aspects of fluency, content, pronunciation, and grammar. In addition to these aspects, the results of these studies also showed that the picture series could maintain learner motivation during the teaching and learning process. Picture series made students more active, creative, independent, and more confident in expressing their ideas. The score obtained from each learning cycle continued to increase (Karsono, 2014; Zainatuddar, 2015; Zulaikah, 
2017). With the existing teachers' belief that relies much on their effort to pass on knowledge and skills of using the target language, it is difficult to change the conditions. Results are still mixed in the use of different techniques used by teachers to improve students' speaking skills.

Because of the success of previous studies regarding Vlog project and picture series, how they performed the teaching and learning process, how these learning techniques succeed in improving speaking skills, and even kindling motivate learners in learning, this article aims to examine the effectiveness in teaching and learning process among the eighth graders of Islamic junior high school.

\section{METHODS}

In this research, the researcher used Nonequivalent-Groups Pretest-Posttest Design. Three classes as the samples were considered as the subject of this study. They were categorized into experimental and control groups. Experimental groups were taught using projectbased learning: vlog projects, and genre-based learning: picture series, while the control group was taught using the conventional technique, which is the teaching technique that the teacher usually uses. Before carrying out the treatment, all groups were given a pre-test. During the research, each group received pre-determined treatment. The same teacher, learning conditions, and learning materials controlled all samples. After conducting treatments, both groups were given a post-test to determine the treatments' effect.

This study was conducted on eighthgraders of an Islamic junior high school in Ciamis, West Java, in the even semester of 2020/2021, from January to March 2021. The 58 students in the three classes are selected using simple cluster random sampling techniques as sample members. The instrument used is a test in the form of an oral speaking test based on the 2013 curriculum and a syllabus for English language education for the eighth grade of junior high school. In order to achieve reliability, three raters, English teachers at the school, assess the students' performance.

Moreover, the researcher used descriptive analysis to get the speaking test results, including mean, max, min, and standard deviation. Besides, inferential analysis was conducted to test the research hypotheses. The researcher had to ensure that the data were distributed normally or not. Therefore, a normality test was conducted. Test of normality was conducted by using Kolmogorov-Smirnov with interpretation if the value of $p$ or asymp. Sig. 2-tailed is more than 0.05 , the distribution of the data does not deviate from the normal distribution (Ghozali, 2018; Nurgiyantoro et al., 2017). Furthermore, the researcher conducted a homogeneity test used One Way ANOVA using Levene Test. The interpretation was that if $\operatorname{sig}>0.05$, then the variances of the groups were homogeneous (Ghozali, 2018; Nurgiyantoro et al., 2017). The researcher took the next step after knowing the data were normally distributed, and the variance which was declared homogeneous was to test hypotheses using the ANOVA test. There is a significant difference if the obtained Sig. value is lower than 0.05 (Ghozali, 2018; Nurgiyantoro, et.al., 2017). Then, the Scheffe test was conducted to know the rank of the effectiveness of the treatments. The researcher used SPSS 16 for windows in all of these calculation processes.

Several things threaten the validity of this research. This threat must be controlled. Therefore, the researcher controlled it by choosing schools with parallel classes to get almost similar classes. Then, the research instrument followed the applicable rules and was validated by a trusted supervisor and validator. In addition, the researcher made two tests with different topics 
and designed ten meetings with different learning activities to avoid monotonously. The research was carried out under conditions using teachers who usually teach English in these classes so that learning runs as it should. Even the researcher was not involved in assessing the students' speaking skills. In addition to validity, stability and consistency are also needed in a study. Reliability in this study was improved by clearly defining the independent and dependent variables. Then, the data measurement carried out in this study only refers to the techniques used in the teaching and learning process of speaking skills to block information from other variables. Furthermore, the data obtained is an accumulation of several indicators of speaking ability in the assessment rubric used. Researchers are guided by quasi-experimental data processing literature written by experts and previous research journals when data processing is carried out. Also, the researcher asked statisticians to carry out validation to ensure that the data calculations were correct.

\section{RESULTS AND DISCUSSION The Result of The Pre-test}

The purpose of the pre-test is to determine the students' speaking skills before the treatment is given. The three sample groups in this study received the same pre-test items. The following is the table 1 that shows the

Table 1. The data comparison between the pre-test of experimental group 1, experimental group 2, and control group

\begin{tabular}{lccccc}
\hline Data & N & Mean & $\begin{array}{c}\text { Std. } \\
\text { Deviation }\end{array}$ & Max & Min \\
\hline $\begin{array}{l}\text { Experimental } \\
\text { Group 1 }\end{array}$ & 19 & 46.94 & 2.527 & 52.00 & 44.00 \\
$\begin{array}{l}\text { Experimental } \\
\text { Group 2 }\end{array}$ & 18 & 47.27 & 2.630 & 52.00 & 44.00 \\
Control Group & 20 & 47.10 & 2.291 & 50.00 & 44.00 \\
\hline
\end{tabular}

comparison of pre-test data from the three sample groups.

Based on table 1, experimental group 1 obtained 44.00 for the lowest score and 52 for the highest score. Then, the mean obtained is 46.94 , and the standard deviation obtained is 2.527. for experimental group 2, the minimum score obtained is 44.00 , and the highest score obtained is 52 . the average score obtained is 47.27 , and the standard deviation is 2.630. while for the control group, the minimum score obtained is 44.00 , and the highest score obtained is 50 . The average score obtained by the students was 47.10 , and the standard deviation obtained is 2.291 .

The results of the data analysis showed that experimental group 2 got the highest achievement in the pre-test. It is indicated by comparing the mean of the three groups, namely $46.9474<47.2778>47.1000$. However, before data analysis using ANOVA was conducted, normality and homogeneity tests on the data obtained were carried out. The normality test is conducted to determine 
Table 2. The results of the normality test on the pre-test

\begin{tabular}{cccc}
\hline Data & $\mathbf{p}$ & $\boldsymbol{\alpha}$ & Interpretation \\
\hline Pre-test of Experimental group 1 & .139 & 0.05 & Normal \\
Pre-test of Experimental group 2 & .200 & 0.05 & Normal \\
Pre-test of Conventional group & .200 & 0.05 & Normal \\
\hline
\end{tabular}

whether the data is in normal condition. The following table 2 shows the results of the normality Table 2 . shows the pvalue or asymp. Sig. (2-tailed) of the pre-test in experimental group 1, experimental group 2 , and control group are more than 0.05 , the indicated values are $0.139>0.05,0.200>$ 0.05 , and $0.200>0.05$. Refers to the existing theory, if the value of $\mathrm{p}$ or asymp. Sig. 2tailed is more than 0.05 , the distribution of the data does not deviate from the normal distribution (Ghozali, 2018; Nurgiyantoro et al., 2017). Accordingly, it can be interpreted that the data obtained is normally distributed.

Moreover, the homogeneity test was performed to determine whether the data

Table 3. Homogeneity test results on the pre-test

\begin{tabular}{lcccc}
\hline & Levene Statistic & df1 & df2 & Sig. \\
\hline Pre-test & .114 & 2 & 54 & .892 \\
\hline
\end{tabular}

obtained before the treatments carried out were homogeneous or not. The homogeneous test result is shown in table 3 .

If the sig. value higher than 0.05 , the data is stated as homogeneous (Ghozali, 2018; Nurgiyantoro et al., 2017). Based on the data in table 3, the Sig. of the pre-test is 0.892 . This score is higher than the significant level, i.e., 0.05. For that reason, the sample variations of the data in the three groups are homogeneous.
Furthermore, ANOVA test was conducted to determine whether there was a significant difference in the pre-test applied to the three groups before the treatment was given. For more details, ANOVA test results are presented in Table 4.

Based on table 4, obtained Sig. 0.921. When viewed from the prevailing theory, there is a significant difference if the Sig. value is lower than 0.05 (Ghozali, 2018 Nurgiyantoro et al., 2017). As a result, the three sample

Table 4. ANOVA test results in the pre-test experimental group 1, experimental group 2, and control group

\begin{tabular}{ccccccc}
\hline Pre-Test & $\begin{array}{c}\text { Sum of } \\
\text { Squares }\end{array}$ & Df & $\begin{array}{c}\text { Mean } \\
\text { Square }\end{array}$ & F & Sig. \\
Groups & 1.010 & 2 & .505 & .082 & .921 \\
\hline $\begin{array}{c}\text { Within } \\
\text { Groups }\end{array}$ & 332.358 & 54 & 6.155 & & \\
\hline Total & 333.368 & 56 & & & \\
\hline
\end{tabular}


groups do not significantly differ in speaking skills. Thus, the three groups are categorized as feasible to research.

\section{The Result of The Post-test}

The post-test was administered to experimental group 1, experimental group 2 , and control group by the researcher after the treatment was given to them. The purpose of the post-test was to determine the difference in speaking skills after the treatment. The following is table 5 which presents a comparison of data between groups.

Table 5 shows that experimental group 1 obtained the lowest score, 60 , and the highest score is 72 . Then the average score obtained was 68.26 , and the standard deviation was 3.124. For experimental group 2, the lowest obtained score was 60 , and The most significant score was 71 . The average obtained was 65.55 , with a standard deviation of 3,484 . In addition, in the control group, the lowest value

Table 5. The comparison of data between the experimental group post-test 1, experimental group 2, and control group

\begin{tabular}{lccccc}
\hline Data & N & Mean & Max. & Min. & Std. Deviation \\
\hline Experimental Group 1 & 19 & 68.26 & 72.00 & 60.00 & 3.124 \\
\hline Experimental Group 2 & 18 & 65.55 & 71.00 & 60.00 & 3.484 \\
\hline Control Group & 20 & 62.80 & 68.00 & 59.00 & 2.984 \\
\hline
\end{tabular}

was 59 , and the enormous score was 68 . The average obtained by this group was 62.80 , and 2,984 is the standard deviation obtained.

When comparing the mean scores of the pre-test and post-test, an increase in scores occurred in all groups. For experimental group 1 , the increase achieved was 21.27 points. Then experimental group 2 experienced an increase of 18.27. while in the control group, the mean score increased by 15.70 points. Of the three groups, experimental group 1 became the group with the highest mean score increase.

Next, the researcher conducted a test on the post-test data obtained to prove the hypotheses in this research were accepted or rejected. Pre-testing must be done before the researcher formulates a hypothesis. For this research, two pre-testing were used, namely the normality test and the homogeneity test. The researcher used SPSS 16 for windows application to perform normality test by using One-Sample Kolmogorov-Smirnov. The following table 6 shows the results of the normality test.

Table 7 shows that the Sig. of the posttest is 0.877 . According to Ghozali, 2018; Nurgiyantoro et al., 2017, if the sig. value higher than 0.05 , then the data is stated as

Table 6. The results of the normality test on the post-test

\begin{tabular}{cccc}
\hline Data & P & $\boldsymbol{\alpha}$ & Interpretation \\
\hline Experimental Group 1 & .088 & 0.05 & Normal \\
\hline Experimental Group 2 & .200 & 0.05 & Normal \\
\hline Control Group & .102 & 0.05 & Normal \\
\hline
\end{tabular}


In the pre-testing analysis, if the value of $\mathrm{p}$ or asymp. Sig. 2-tailed is more than 0.05 , the distribution of the data does not deviate from the normal distribution (Ghozali, 2018; Nurgiyantoro et al., 2017). So, if the results obtained are lower than 0.05 , the data is not in a normal distribution state. Table 6 . shows that the p-value or Asymp. Sig. (2-tailed) in the post-test experimental group 1, experimental group 2, and control group are more than 0.05 . So, the post-test in all three groups is considered a normal distribution and eligible for further statistical analysis. Then, the next test is the homogeneity test. Levene test was used to test homogeneity. The results of the test are shown more clearly in Table 7.

Table 7. Homogeneity test results on the post-test

\begin{tabular}{lcccc}
\hline & $\begin{array}{c}\text { Levene } \\
\text { Statistic }\end{array}$ & df1 & df2 & Sig. \\
\hline Post-test & .132 & 2 & 54 & .877 \\
\hline
\end{tabular}

homogeneous data. It means that the data in the three groups are higher than the significance level and regarded as homogeneous and eligible for further analysis, testing the hypotheses.

Hypotheses testing was conducted to determine whether the developed hypotheses were accepted or not. The test used the
ANOVA test, then it was followed by the Scheffe test. ANOVA test was used to test the significance of treatment in the teachinglearning process using the vlog project, picture series, and conventional techniques. The Scheffe test was used to determine treatment rank. The results of the ANOVA test are presented in table 8 .

Table 8. ANOVA test results on the post-test in the experimental group 1, experimental group 2, and the control group

\begin{tabular}{ccccccc}
\hline & & $\begin{array}{c}\text { Sum of } \\
\text { Squares }\end{array}$ & df & Mean Square & F & Sig. \\
\hline $\begin{array}{c}\text { Post- } \\
\text { test }\end{array}$ & $\begin{array}{c}\text { Between } \\
\text { groups }\end{array}$ & 290.917 & 2 & 145.458 & 14.247 & .000 \\
\hline & $\begin{array}{c}\text { Within } \\
\text { Groups }\end{array}$ & 551.329 & 54 & 10.210 & & \\
\hline & & & & & \\
\hline
\end{tabular}

There is a significant difference between the sample groups when the Sig. score lower than 0.05 (Ghozali, 2018; Nurgiyantoro, et.al., 2017). Furthermore, a significant difference between experimental group 1, experimental group 2, and control group are exists. The obtained Sig. 0.000 is evidence that, which is lower than 0.05. After that, the analysis was continued with the Scheffe test. This test aimed to determine the treatment's rank and prove all the hypotheses designed in this research. The results are shown in Table 9. 
Table 9. Scheffe test results

\begin{tabular}{|c|c|c|c|c|c|c|c|}
\hline \multirow[t]{2}{*}{$\begin{array}{l}\text { Dependent } \\
\text { Variable }\end{array}$} & \multirow[t]{2}{*}{ (I) Group } & \multirow[t]{2}{*}{ (J) Group } & \multirow{2}{*}{$\begin{array}{c}\text { Mean } \\
\text { Difference } \\
\text { (I-J) }\end{array}$} & \multirow[t]{2}{*}{$\begin{array}{c}\text { Std. } \\
\text { Error }\end{array}$} & \multirow[t]{2}{*}{ Sig. } & \multicolumn{2}{|c|}{$\begin{array}{l}\text { 95\% Confidence } \\
\text { Interval }\end{array}$} \\
\hline & & & & & & $\begin{array}{l}\text { Lower } \\
\text { Bound }\end{array}$ & $\begin{array}{l}\text { Upper } \\
\text { Bound }\end{array}$ \\
\hline \multirow[t]{6}{*}{ Post-test } & \multirow[t]{2}{*}{$\begin{array}{l}\text { Experimental } \\
\text { Group } 1\end{array}$} & $\begin{array}{l}\text { Experimental } \\
\text { Group } 2\end{array}$ & $2.70760 *$ & 1.05098 & .044 & .0620 & 5.3532 \\
\hline & & $\begin{array}{l}\text { Control } \\
\text { Group }\end{array}$ & $5.46316^{*}$ & 1.02364 & .000 & 2.8864 & 8.0399 \\
\hline & \multirow[t]{2}{*}{$\begin{array}{l}\text { Experimental } \\
\text { Group } 2\end{array}$} & $\begin{array}{l}\text { Experimental } \\
\text { Group 1 }\end{array}$ & $-2.70760^{*}$ & 1.05098 & .044 & -5.3532 & -.0620 \\
\hline & & $\begin{array}{l}\text { Control } \\
\text { Group }\end{array}$ & $2.75556^{*}$ & 1.03812 & .036 & .1424 & 5.3688 \\
\hline & \multirow[t]{2}{*}{$\begin{array}{l}\text { Control } \\
\text { Group }\end{array}$} & $\begin{array}{l}\text { Experimental } \\
\text { Group } 1\end{array}$ & $-5.46316^{*}$ & 1.02364 & .000 & -8.0399 & -2.8864 \\
\hline & & $\begin{array}{l}\text { Experimental } \\
\text { Group } 2\end{array}$ & $-2.75556^{*}$ & 1.03812 & .036 & -5.3688 & -.1424 \\
\hline
\end{tabular}

The first hypothesis states, "the use of vlog project is more effective than picture series as teaching techniques in teaching recounts in speaking skills." This hypothesis is accepted with the indications shown in table 9, namely obtained Sig. is 0.044 . It is lower than 0.05 . Then it is suggested that the performance of experimental group 1 is better than experimental group 2 as shown by the obtained mean difference is positive with a score of 2.70760 .

The data analysis results show a significant difference between the vlog project and picture series techniques. This finding is supported by previous studies conducted by Hung (2011) and Anil (2016), where both studies show that the use of vlog projects achieves good results and successfully improves speaking skills.

In teaching and learning speaking, vlog projects are more practical to use. The technique gives students space to practice longer because it is not limited to time for use during school hours. Because of this, their ability to master vocabulary and grammar increases. It is in line with Watkins (2012), which claims that vlogging increases the time for learners to talk. The longer students have to communicate verbally, the more students' mastery of vocabulary addition and grammar mastery will increase. Therefore, using the vlog project technique, students can set their own speaking practice time without thinking about the minimal learning time limit in class. In addition, if the students are not satisfied with the vlogs they have made, they still have the opportunity to repeat the vlogs while still working on the project. They can repeat it until they find it satisfactory. Under what Hung (2011) expresses, students have a longer time limit than doing class assignments. Thus, learners can repeat project work if it is not at the satisfying stage yet.

The second hypothesis proposes, "Vlog project is more effectively used than conventional technique in learning speaking skills." This hypothesis is also confirmed to be accepted because based on Scheffe's test, 
the Sig. value indicates 0.000 , which is lower than 0.05 . In addition, the experimental group 1 performance is better than the control group because the mean difference is positive with 5.46316 .

Based on the analysis results, the vlog project technique is also more effective than conventional techniques. The students who received treatment using the vlog project technique got a higher mean post-test score than the students in the control group. Similar results were also recorded in a study conducted by Marzuki \& Nurpahmi (2019); and Ahsin (2020).

In applying the teaching and learning process using the vlog project technique, learning is student-centered. The teacher only serves as a guide and provides opinions and input when needed. Furthermore, when determining the topic for the project to be worked on, the teacher only provides a general theme, which is more specific to be decided by the students. This idea is supported by Stoller (2002), who identifies that project work is student-centered. The teacher only has a role as a supporter and giver of direction in the project completion process. Similarly, Krauss \& Boss (2013) and Kýzapan \& Bektap (2017) explain that project-based learning is student-centered. In this teaching technique, learners must solve the problems they face and seek information related to the projects they are working on to theorize, investigate, collect, analyze, create, and draw conclusions from the valuable information.

On the other hand, in the teaching and learning process carried out in the control class using the conventional technique, the teaching and learning process only runs in one direction. The teacher controls a substantial portion of it. The teacher explains the material then gives exercises to do. In addition, the learners play a passive role because the teacher has determined everything. It is in line with Sanjaya (2006) and Djafar (2001), where the conventional technique is a learning process that places students as learning objects that have the role of passively receiving learning information. It is a learning process where the teacher becomes the centre. In the learning process, learners only carry out two activities: listening and taking notes or oneway learning. It is inversely proportional to the learning activities conducted using the vlog project technique. In the implementation of learning using conventional technique, learners only listened to the material described by the teacher and did the tasks that had been provided. That is also supported by Djamarah \& Zain (2006), who describe that conventional learning has the characteristics of delivering learning material through lectures followed by explanatory activities and assignments and exercises.

The third hypothesis claims, "the use of picture series is more effective than the use of the conventional technique as teaching techniques in teaching recounts in speaking skills." Scheffe test was performed to prove this hypothesis. The score of Sig. indicates this. The obtained Sig. is 0.036 . it is lower than 0.05 . Moreover, the results obtained for the mean difference show a positive outcome with score 2.75556, which means that experimental group 2 has appeared better than the control group. Because of that, picture series is statistically more effective than conventional technique.

When the picture series and conventional techniques are compared, based on the analysis done in this study, picture series is more effective. The results of the research conducted by Purwatiningsih (2015) adds the same thing that showed the results that the learners' speaking skills increased. Similar results are also demonstrated in research conducted by 
Karsono (2014), Zainatuddar (2015), and Zulaikah (2017), where the results showed that picture series could help learners developed their speaking skills in the aspects of fluency, content, and grammar.

The students' curiosity was tried to be aroused by the teacher through the pictures presented in the teaching and learning process in this study. That is realized through activities such as made observations, then discussed with each other, and asked questions about these pictures. The students' critical sense is also sharpened because they ask questions about their observations of the pictures presented. The students were asked to look for other texts of the same type to practice their knowledge of tenses used so that recount text can be built smoothly. In addition, pictures can also help students to tell the events. It was a challenge, but they were permitted to see the series of pictures as they spoke. It is in line with Wright (1989), who identifies that in picture series, pictures arranged in sequence can help learners to gather ideas and make it easier for learners to put lines of events. In one series of pictures, there are usually three to ten pictures. This picture series is used to provide challenges and also arouse the learner's desire to tell stories.

Unlike the teaching and learning process using the conventional technique in the control group, students only undergo one-way communication and listen to the explanation of the learning material from the teacher and continue with exercises to answer the questions given or do the tasks given. This idea is supported by Nasution (1982); Ruseffendi (2005); Djamarah \& Zain (2006) who explain that the learning process in conventional technique is passive and dominated by teachers and does not provide much feedback given in learning. It is done through lectures and assignments. Besides, teaching materials are given to the entire group of students without any attention to each individual.

The fourth hypothesis states, "the vlog project technique is the most effective teaching technique in teaching recounts in speaking skills." This hypothesis is also accepted. It is indicated by the mean difference between experimental group 1 is positive for the other groups. It is evidence that vlog project is, based on the statistical comparison in the table 9, the most effective technique in learning speaking skills.

From this research, if the level of effectiveness in using learning techniques is ranked, the vlog project is in the first place, then in the second place is the picture series, and in the last slot is occupied by conventional techniques. In other words, in this research, the vlog project technique is the most effective technique used in speaking, especially in the recount genre.

Because of vlog project effectiveness, further review on the advantages was conducted. The following are the advantages possessed by the vlog project technique that picture series and conventional techniques seem not to have. The first advantage is that it takes longer to complete the task. In the vlog project technique, the learning process occurs in the classroom and outside the classroom so that students have a longer time to study the material provided and have a longer time to do the tasks given so that they have time to improve the tasks given many times. The project execution time given in this study is one week. In this case, it also provides a more extended practice opportunity to improve their speaking skills performance. It is in line with what was said by Hung (2011), the vlog project could be considered as an interactive activity, students had a longer time limit than doing assignments in class thus they were able to repeat project work if they were not at the 
satisfying stage yet. Meanwhile, in this research, the picture series and conventional learning techniques were carried out only during class hours so that the learning time was shorter than the vlog project technique. Nasution, 1982; Ruseffendi, 2005; Djamarah \& Zain (2006) express that conventional techniques do not require a long time in learning because the activity focused on explaining the material that many learners can follow.

The second, in the teaching-learning process using the vlog project technique, students have the opportunity to assess their performance. They can try to listen and examine whether there are still inappropriate pronunciations or grammar errors through recorded videos. This idea is supported by Watkins (2012), which claims that if the students are not satisfied with the vlogs they have made, they still have the opportunity to repeat the vlogs while they are still working on the project. They can repeat it until they find it satisfactory (Watkins, 2012). On the other hand, in this study, assessing performance by themselves is challenging in the teaching and learning process using picture series and conventional techniques because of the limited learning time in class, which only lasts 90 minutes.

\section{CONCLUSIONS}

From the discussion, it can be concluded that the vlog project technique significantly affects the teaching and learning process of speaking in the eighth grade of Islamic junior high school. Moreover, there is a significant difference in the achievement of speaking skills of eighth grade Islamic junior high school students who are taught using vlog project and picture series techniques. Based on a conducted examination between the vlog project technique and the picture series technique, the most effective technique used in the teaching-learning process of speaking skills in this research is the vlog project technique.

\section{REFERENCES}

Ahsin, M. (2020). The effect of project based learning based vlog on student's speaking skill across different personality. Language-Edu: Journal of English Teaching and Learning, 9(2), 1-11.

Amsiana, L., Suparman, U., \& Sudirman. (2014). Teaching of reading comprehension of narrative through short story and picture series. UNILA Journal of English Teaching, 3(4), 1-10.

Andayani, T., \& Arono. (2016). Improving students' ability in writing narrative text by using picture series for the eighthgrade students of junior high school. Journal of Applied Linguistics and Literature, 2(2), 1-10.

Anil, B. (2016). Top-up students second language talk time through vlogs. Indonesian Journal of EFL and Linguistics, 1(2), 129-143.

Bailey, K. M. (2005). Practical english language teaching: speaking. New York: McGraw Hill.

Brown, H. D. (2000). Principles of Language Learning and Teaching (4th Edition). New York: The Free Press.

Djafar, T. (2001). Kontribusi Strategi Pembelajaran [Learning strategy contribution]. Yogyakarta:Andi.

Djamarah, S. B dan Zain, A. (2006). Strategi Belajar Mengajar [Teaching and learning strategy]. Jakarta; Rineka Cipta.

Harmer, J. (1991). The practice of english language teaching. London: Longman.

Harmer, J. (2004). How to teach writing. New York: Pearson Education Ltd. 
Hung, S. (2011). Pedagogical applications of vlogs: an investigation into ESP learners' perceptions. British Journal of Educational Technology, 42(5), 736746.

Iman, J. N., \& Angraini, N. (2016). Using picture-series based instruction to improve speaking and writing achievements of the EFL undergraduate students. Global Expert Jurnal Bahasa Dan Sastra, 5(1), 16- 23.

Karsono, P. (2014). Using pictures in improving the speaking ability of the grade eight-a students of SMP Negeri 1 Anggana. Dinamika Ilmu, 14(2), 190- 213.

Kýzkapan, O., \& Bekta ${ }^{\circ}$, O. (2017). The effect of project based learning on seventh grade students' academic achievement. International Journal of Instruction, 10(1), 37-54.

Krauss, J., \& Boss, S. (2013). Thinking through project based learning guiding deeper inquiry. London: SAGE Publications Ltd.

Marmah, A.A. (2014). Students 'perception about the lecture as a method of teaching in tertiary institutions, views of students from college of technology eduction , Kumasi (COLTEK). International Journal of Education and Research, 2(6), 601- 612.

Marzuki, M \& Nurpahmi, S. (2019). Using video blog in teaching speaking. English Language Teaching for EFL Learners. 1(13), 13- 23.

Mokhtar,Alia. (2016). Rethinking conventional teaching in language learning and proposing edmodo as intervention: a qualitative analysis. Malaysian Online Journal of Educational Technology, 4(2), 22-37.

Nasruloh, M. I. (2013). Teacher-student interaction in a project-based learning classroom. Journal of English and Education, 1(1), 142-153.
Nasution, S. (1982). Berbagai pendekatan dalam proses belajar mengajar [Various approaches in the teaching and learning process]. Jakarta: Bina Aksara.

Nugroho, L., Sudirman, \& Hasan, H. (2015). The use of picture series in improving students speaking recount text skill. UNILA Journal of English Teaching, 4(1), 1-9.

Nurgiyantoro, B., Gunawan, \& Marzuki,. (2017). Statistik terapan untuk penelitian ilmu sosial [Applied statistics for social science research]. Yogyakarta: Gadjah Mada University

Patton, A. (2012). Work that matters: the teacher's guide to project-based learning. London: The Paul Hamlyn Foundation.

Pratiwi, D. (2016). Improving the tenth grade students' writing skill by using picture series. Journal of English Language and Education, 2(1), 11- 17.

Purwatiningsih. (2015). Improving speaking ability through story telling technique by using picture series. Journal on English as a Foreign Language, 5(1), 57- 66.

Rahmawati, A., Harmanto, B., \& Indriastuti, N. R. (2018). The use of vlogging to improve the students' speaking skill. EDUPEDIA, 2(1), 87-95.

Rakhmanina, L., \& Kusumaningrum, D. (2017). The effectiveness of video blogging in teaching speaking viewed from students' learning motivation. The 5th International Seminar on English Language and Teaching (ISELT) 2017, 27- 34. May, 2017. Padang, Indonesia: ISELT FBS Universitas Negeri Padang.

Richards. J.C. (2008). Teaching listening and speaking from theory to practice. New York: Cambridge University Press.

Richard, J. C., \& Renandya,W. A. (2002). Methodology in language teaching: an 
anthology of current practice. Cambridge: Cambridge University Press.

Ruseffendi. (2005). Dasar-dasar penelitian pendidikan \& bidang non-eksata lainnya [Research fundamentals in education \& other non-exact fields]. Bandung: Tarsito.

Sanjaya, W.(2006). Strategi pembelajaran [Learning strategies]. Jakarta: Kencana

Prenada Media Group.

Stoller, F. L. (2002). Project work: a means to promote language and content. In Jack C. R \& Renandya, W.A, Methodology in language teaching: an anthology of current practice. Cambridge: Cambridge University Press.

Spartt, M., Pulverness, A., \& Williams, M. (2005). The TKT (Teaching Knowledge Test) course. Cambridge: Cambridge University Press.

Thornbury, S. (2005). How to teach speaking. Harlow: Pearson Education Limited.
Watkins, J. (2012). Increasing student talk time through vlogging. Language Education in Asia, 3(2) 196- 203.

Wright, A. (1989). Picture for language learning. New York: Cambridge University Press.

Yap, W. L. (2016). Transforming conventional teaching classroom to learner-centred teaching classroom using multimedia mediated learning module. International Journal of Information and Education Technology, 6(2), 105112.

Zainatuddar. (2015). Teaching speaking in english by using the picture series technique. English Education Journal, 6(4), 443-456.

Zulaikah. (2017). The student's speaking ability of the tenth grade gtudents of SMA 2 Genteng Through Picture Series. Channing: Journal of English Language Education and Literature. 2(2), 69-77. 